\author{
Available online at JECE (Journal of Early Childhood Education) \\ Website: http://journal.uinjkt.ac.id/index.php/jece \\ Permalink/DOI: http://dx.doi.org/10.15408/jece.v1i2.13312 \\ JECE, 1 (2), Desember 2019, 29-44
}

\title{
METODE PENANAMAN NILAI-NILAI AGAMA DAN MORAL ANAK USIA DINI
}

\author{
Novia Safitri, Cahniyo Wijaya Kuswanto, Yosep Aspat Alamsyah \\ Universitas Islam Negeri Raden Intan Lampung, Indonesia \\ corresponding e-mail: noviasafitri45@gmail.com
}

\begin{abstract}
The cultivation of moral and religious values in early childhood is very important so that students can have good moral and religious values, so that when students enter the next level, they already have knowledge, good experiences that have been obtained when they at the time pre school. This study discusses the cultivation of religious and moral values of early childhood in Goemerlang Sukarame Kindergarten, Bandar Lampung. The purpose of this study was to determine the cultivation of moral and religious values in early childhood in Goemerlang Sukarame Kindergarten, Bandar Lampung. This research is a descriptive qualitative study, which involves a teacher in class B2. Data were analyzed qualitatively using data reduction, data display, and conclusion drawing. The results showed that the activities of planting moral and religious values in Goemerlang Bandar Lampung Kindergarten had been well planned and implemented. There are several methods developed at Goemerlang Bandar Lampung Kindergarten for inculcating moral and religious values, namely the story telling method, the field trip method, the demonstration method, the assignment method, the habituation method, and the conversation method.
\end{abstract}

Keywords: moral and religious values, early childhood, values cultivation

\begin{abstract}
Abstrak
Penanaman nilai-nilai moral dan agama pada anak usia dini sangat penting dilakukan agar peserta didik dapat memiliki nilai-nilai moral dan agama yang baik, sehingga ketika peserta didik memasuki jenjang selanjutnya maka sudah mempunyai pengetahuan, pengalaman yang baik yang sudah didapatkan ketika mereka pada saat pra sekolah. Tujuan dari penelitian ini adalah untuk mengetahui penanaman nilai-nilai moral dan agama pada anak usia dini di TK Goemerlang Sukarame Bandar Lampung. Penelitian ini merupakan penelitian kualitatif deskriptif, yang melibatkan seorang guru di kelas B2. Data yang dianalisis secara kualitatif dengan menggunakan cara reduksi data, display data, dan penarikan kesimpulan. Hasil penelitian menunjukkan bahwa kegiatan penanaman nilai-nilai moral dan agama di TK Goemerlang Bandar Lampung sudah terencana dan terlaksana dengan baik. Ada beberapa metode yang dikembangkan di TK Goemerlang Bandar Lampung untuk penanaman nilai-nilai moral dan agama, yaitu metode bercerita, metode karyawisata, metode demonstrasi, metode pemberian tugas, metode pembiasaan, dan metode bercakap-cakap.
\end{abstract}

Kata Kunci: nilai moral dan agama, anak usia dini, penanaman nilai 


\section{Pendahuluan}

Pendidikan Anak Usia Dini merupakan salah satu bentuk penyelenggaraan pendidikan yang menitikberatkan pada peletakan dasar ke arah pertumbuhan dan perkembangan fisik (koordinasi motorik halus dan kasar), kecerdasan (daya pikir, daya cipta, kecerdasan emosi, kecerdasan spiritual), sosio emosional (sikap dan perilaku serta beragama), bahasa dan komunikasi, serta dengan keunikan dan tahap-tahap perkembangan yang dilalui oleh anak usia dini (Yuliani Nurani, 2013: 6). Pendidikan Anak Usia Dini dinyatakan dalam Undang-undang Nomor 20 Tahun 2003 tentang Sistem Pendidikan Nasional Bab 1 Pasal 1 Ayat 14,

"Pendidikan anak usia dini adalah suatu upaya pembinaan yang ditujukan kepada anak sejak lahir sampai dengan usia enam tahun yang dilakukan melalui pemberian rangsangan pendidikan untuk membantu pertumbuhan dan perkembangan jasmani dan rohani agar anak memiliki kesiapan dalam memasuki pendidikan lanjut" (Kemendiknas, 2014: 2).

Pendidikan nilai-nilai moral agama pada program PAUD merupakan fondasi yang kokoh dan sangat penting keberdaanya, dan jika hal itu telah tertanam dengan baik dalam setiap insan sejak dini, hal tersebut merupakan awal yang baik bagi pendidikan anak bangsa untuk menjalani pendidikan selanjutnya. Bangsa indonesia sangat menjunjung tinggi nilai-nilai moral agama. Nilai-nilai luhur ini pun dikehendaki menjadi motivasi spritual bagi bangsa ini dalam rangka melaksanakan sila-sila lainnya dalam pancasila. Firman Allah SWT dalam surat Luqman ayat 14:

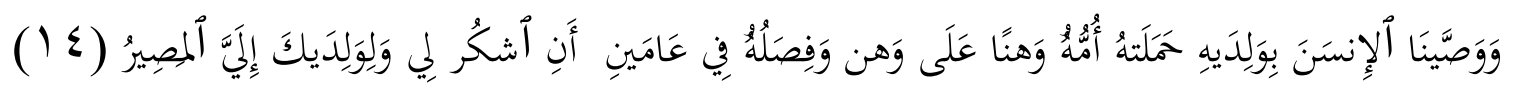

Artinya: Dan Kami perintahkan kepada manusia (berbuat baik) kepada dua orang ibubapaknya; ibunya telah mengandungnya dalam keadaan lemah yang bertambah-tambah, dan menyapihnya dalam dua tahun. Bersyukurlah kepada-Ku dan kepada dua orang ibu bapakmu, hanya kepada-Kulah kembalimu

Tabel 1

Indikator Perkembangan Nilai-Nilai Moral Agama

Pada Anak Usia Dini

\begin{tabular}{|c|c|c|}
\hline Ruang Lingkup & $\begin{array}{c}\text { Tingkat Pencapaian } \\
\text { Perkembangan Usia 5-6 Tahun }\end{array}$ & Indikator \\
\hline \multirow{3}{*}{$\begin{array}{l}\text { Nilai-nilai moral } \\
\text { agama }\end{array}$} & $\begin{array}{l}\text { 1. Membiasakan diri } \\
\text { Beribadah }\end{array}$ & $\begin{array}{l}\text { 1. Berdo'a sebelum dan sesudah } \\
\text { melaksanakan kegiatan }\end{array}$ \\
\hline & $\begin{array}{l}\text { 1. Memahami perilaku } \\
\text { (jujur, penolong, } \\
\text { hormat, dsb. }\end{array}$ & $\begin{array}{l}\text { 1. Berbicara dengan sopan } \\
\text { 2. Menghormati guru dan orang } \\
\text { yang lebih tua } \\
\text { 3. Mau terbiasa menunggu antrian }\end{array}$ \\
\hline & $\begin{array}{l}\text { 1. Membedakan perilaku baik } \\
\text { dan buruk }\end{array}$ & $\begin{array}{l}\text { 1. Menunjukkan perbuatan- } \\
\text { perbuatan yang benar dan salah }\end{array}$ \\
\hline
\end{tabular}

Vol. 1 No. 2 | $30-44$

Copyright (C 2019 | JECE | P-ISSN 2686-2492 
Menurut Piaget Penanaman nilai-nilai moral dan agama anak mampu berfikir dengan dua proses yang sangat berbeda tentang moralitas tergantung pada kedewasaan perkembangan mereka (Rizki Ananda, 2017: 22-23). Piaget juga mengatakan bahwa seseorang manusia di dalam kehidupan akan mengalami rentangan perkembangan moral yaitu : a) tahap heteronomous yaitu cara berfikir anak dimana keadilan peraturan yang bersifat objektif artinya tidak dapat diubah dan tidak dapat ditiadakan oleh manusia. b) tahap autonomous yakni anak mulai menyadari adanya kebebasan untuk tidak sepenuhnya menerima aturan itu sebagai hal yang datang dari luar dirinya (John W. Santrock, 2013: 117-118).

Menurut Kohlberg perkembangan moral agama anak tidak memusatkan perhatian pada perilaku moral, artinya apa yang dilakukan oleh seorang individu tidak menjadi pusat pengamatannya. Ia menjadikan penalaran moral sebagai pusat kajiannya. Dikatakannya bahwa mengamati perilaku tidak menunjukkan banyak mengenai kematangan moral. Seorang dewasa dengan seorang anak kecil barang kali perilakunya sama, tetapi seandainya kematangan moral mereka berbeda, tidak akan tercermin dalam perilaku mereka.

Menurut Syaodih menyatakan bahwa perkembangan nilai-nilai moral dan agama anak usia dini antara lain: anak bersikap imitasi (imitation) yakni mulai menirukan sikap, cara pandang serta tingkah laku oranglain, anak bersikap internalisasi yakni anak sudah mulai bergaul dengan lingkungan sosialnya dan mulai terpengaruh dengan keadaan di lingkungan tersebut, anak bersikap introvert dan ekstrovert yakni raksi yang ditujukkan anak berdasarkan pengalaman (Erna Purba, 2013: 4). Menurut John Dewey, tahapan perkembangan moral seseorang ada pada tahap pra konvensional yang memiliki karakteristik sikap dan perilaku anak dilandasi oleh implus biologis dan social (Asti Inawati, 2013: 4). Menurut Ahmad Nawawi, pendidikan nilai moral adalah suatu usaha sadar yang dilakukan oleh manusia (orang dewasa) yang terencana untuk memberikan kesempatan kepada peserta didik (anak, generasi penerus) menanamkan ketuhanan, nilai-nilai estetik dan etik, nilai baik dan buruk, benar dan salah, mengenai perbuatan sikap dan kewajiban; akhlak mulia, budi pekerti luhur agar mencapai kedewasaannya dan bertanggung jawab (Mulianah Khaironim, 2017: 3).

Peningkatan potensi spiritual anak melalui pengalaman agar menjadi kebiasaan, baik di dalam maupun di luar sekolah. Adapun penanaman nilai-nilai moral dan agama yang diberikan oleh guru di kelas yaitu dengan metode bercerita, demonstrasi, pemberian tugas, karyawisata, pembiasaan dan bercakap-cakap. Nilai moral dan agama sangat berperan dalam membentuk perilaku anak sehingga anak mampu berinteraksi dan bersikap sesuai pertumbuhan dan perkembangannya, 
Untuk itu diperlukan pengawasan serta pemeliharaan yang berlangsung secara terus menerus untuk pembentukan kebiasaan dan sikap anak.

Pada dasarnya, penanaman nilai-nilai moral dan agama sejak dini membentuk naluri anak untuk menerima sikap keutamaan dan kemuliaan, dan akan terbiasa melakukan akhlak mulia. Dengan masalah tersebut peneliti ingin meneliti tentang Penanaman Nilai-nilai Moral dan Agama Anak Usia Dini. Penulis tertarik untuk melakukan penelitian kualitatif deskriptif dengan judulpenanaman nilai-nilai moral dan agama anak usia dini di TK Goemerlang Sukarame Bandar Lampung.

Hal ini selaras dengan penelitian terdahulu, yang dilakukan Muhammad Ali Saputra yang berjudul penanaman nilai-nilai agama pada anak usia dini di RA.DDI Addariyah Palopo City. Pada penelitian ini dijelaskan bahwa penanaman nilai-nilai agama pada peserta didik di RA DDI Addariyah Palopo mengintegrasikan kurikulum kementrian pendidikan nasional (Kemendiknas) maupun metode penanaman. Sebagai faktor pendukung, para guru memiliki motivasi yang tinggi kendatipun tidak diimbangi dengan pendapatan yang memadai dalam melakukan tugasnya. Sedangkan minimnya fasilitas dan kurang nya pendanaan dapat menjadi faktor penghambatnya. Sebagai rekomendasi, kemenag dapat memberi perhatian dan bantuan untuk meningkatkan fasilitas bagi lembaga-lembaga pendidikan usia dini tersebut maupun memberi pelatihan secara regular kepada para gurunya.

Berdasarkan penjelasan yang telah dipaparkan di atas maka penulis tertarik untuk melakukan penelitian yang berjudul "Penanaman Nilai-Nilai Moral Dan Agama Anak Usia Dini Di TK Goemerlang Bandar Lampung".

\section{Metode}

Penelitian ini menggunakan pendekatan kualitatif deskriptif. Tujuan dari penelitian ini untuk memberikan gambaran secara objektif tentang fakta yang ada dilapangan dalam hal ini tempat penelitian. Berdasarkan hasil observasi, wawancara dan dokumentasi terhadap guru di TK Goemerlang Sukarame Bandar Lampung berkaitan dengan penanaman moral dan agama anak usia dini.

Adapun alasan Penelitian ini menggunakan jenis penelitian dekriptif karena peneliti ini ingin melihat penanaman nilai agama dan moral pada anak usia dini. Dalam mengumpulkan data, peneliti melakukan tehnik dan alat pengumpulanya menggunakan observasi, wawancara dan dokumentasi. Sedangkan metode pengumpulan data pada penelitian ini menggunakan jenis wawancara semi terstruktur artinya peneliti mengajukan beberapa pertanyaan secara lebih bebas dan terbuka, tanpa terikat oleh suatu susunan pertanyaan yang telah dipersiapkan sebelumnya (Sugiyono, $2014:$ 233)

Beberapa aspek yang dilakukan observasi dalam penelitian ini, yaitu tentang metode penanaman nilai agam dan moral yang digunakan oleh guru. Kemudian 
peneliti mencatat semua hal yang diperlukan selama pelaksanaan tidakan berlangsung. Pengematan ini dengan menggunakan lembar observasi dengan memberikan tanda chelist pada hasil pengamatan. Lembar observasi ini dibuat dijadikan sebuah pedoman oleh peneliti, agar penelitian yang dilakukan lebih akurat, terstruktur dan terarah sehingga nantinya hasil data yang diperoleh mudah di sekolah. Hasil dokumentasi penelitian ini berupa profil sekolah, visi dan misi, data peserta didik, dan juga dokumen yang berkaitan dengan proses kegiatan penanaman nilai-nilai moral dan agama anak usia dini.

Ada beberapa Analisis data yang dapat diperoleh dari hasil penelitian ini. Adapun langkah-langkah yang dilakukan dalam prosedur analisis data adalah sebagai berikut : a). Reduksi Data (Data Reduction), yaitu melakukan pencatatan secara rinci dan teliti karena banyaknya data yang diperoleh dari lapangan cukup banyak. Sehingga data yang telah direduksi mampu memberikan gambaran yang jelas dan membantu peneliti untuk melakukan pengumpulan data selanjutnya serta mencari data tersebut jika diperlukan. Adapun data yang dianggap relevan dan penting yaitu data yang berkaitan tentang peran guru di alam penanaman nilai moral agama anak usia dini di TK Goemelang Sukarame Bandar Lampung; b). Penyajian Data (Display Data).setelah melakukan reduksi langkah selanjutnya adalah mendisplaykan data.Sehingga mudah dipahami oleh peneliti Maupun orang lain yang membacanya. Adapun bentuk penyajian datanya dalam bentuk naratif, yang berararti analisis berdasarkan observasi dilapangan dan pandangan secara teoritis untuk memebrikan gambaran secara jelas tentang pendidik dalam penanaman nilai moral moral agama anak usia dini di TK Goemerlang Sukarame Bandar Lampung; c). Penarikan Kesimpulan/ Verifikasi (Conclusion Drawing/Verification).Harapan dari penelitian kualitatif adalah temuan baru atau menggambarkan suatu objek yang sebelum nya belum jelas sehingga menjadi jelas dan dapat dipahami oleh orang. Kesimpulan ini tentunya masih sebagai hipotesis dan bisa menjadi teori jika didukung oleh data-data yang lain. Data yang telah didapatkan, kemudian dirincikan dan disusun secara sistematis dalam betuk naratif. Kemudian data tersebut disimpulkan sehingga data dapat ditemukan dalam bentuk tafsiran dan argumentasi.

Triangulasi pada keabsahan sebagai pengecekan data dari berbagai sumber, cara dan waktu. Triangulasi sumber, untuk menguji data dilakukan dengan cara mengecek data yang telah diperoleh melalui beberapa sumber, triangulasi teknik, untuk menguji kredibilitas data yang dilakukan dengan cara mengecek data kepada sumber yang sama dengan teknik yang berbeda. Misalanya data yang diperoleh dengan wawancara, lalu dicek dengan observasi, dokumentasi atau kuisioner.

\section{Hasil dan Pembahasan}

Vol. 1 No. 2 | 33-44 
Pada Bab ini penulis akan menjelaskan hasil penelitian beserta pembahasanya. Data yang diolah dan dianalisis merupakan data kualitatif yang diperoleh melalui proses triangulasi yaitu observasi, wawancara dan dokumentasi pada Guru mengenai Penanaman Nilai-Nilai Moral Dan Agama Anak Usia Dini Di Tk Goemerlang Bandar Lampung.berdasarkan hasil penelitian yang telah dilakukan oleh peneliti, dapat kita lihat bahwa Hasil penelitian menunjukan bahwa kegiatan Penanaman Nilai-nilai Moral dan Agama di Tk Goemerlang Bandar Lampung dilakukan menggunakan berbagai metode antara lain: bercerita, karyawisata, demonstrasi, pemberian tugas, pembiasaan, dan bercakap-cakap. Berikut ini pembahasan secara detailnya:

1. Metode Bercerita

Berdasarkan hasil observasi yang dilakukan oleh peneliti di TK Goemerlang Sukarame Bandar lampung, ada beberapa penejelasan tentang metode bercerita yang dilakukan guru dalam menanamkan nilai agama dan moral pada anak, yaitu:

a. Menentukan tujuan dan tema yang dipilih untuk ekgiatan bercerita. Berdasarkan hasil penelitian ini, penentuan tujuan dan tema telah tertuang di RPPH.

b. Menetapkan rancangan cerita. Setelah tujuan dan tema sudah terpilih, selanjutnya menetapkan rancangan bentuk bercerita. Dalam bercerita guru menggunakan boneka tangan, dengan berbagai cerita sepertitentang kisahkiasah nabi, keutamaan sholat, jumlah rokaat dalam sholat, Agama yang dianut, macam-macam agama yang ada, Guru menceritakan dihadapan peserta didik dan dimana peserta didik mendengar cerita dari guru tersebut dengan seksama.

c. Menetapkan bahan dan alat yang diperlukan untuk kegiatan bercerita. Langkah selanjutnya setlah menentukan tujuan, tema dan rancangan cerita gurumenyiapkan bahan dan alat yang akan digunakan dalam proses bercerita, Seperti boneka tangan, gambar macam-macam agama, dll. Tentunya yang berhubungan dengan penenaman nilai agama dan moral peserta didik sesuai dengan cerita yang di rancang. Selanjutnya guru meminta peserta didik untuk duduk di ruang kelas belakang untuk mendengarkan cerita guru.

d. Menetapkan rancangan langkah kegiatan bercerita. Langkah selanjutnya adalah melakukan rancangan kegiatan bercerita. Dengan beberapa langkah yang buat antara lain guru memberikan penjelasan kepada peserta didik bahwa hari ini bu guru akan menceritakan tentang guru menceritakan tentang kisah-kisah Nabi, keutamaan shalat, jumlah rokaat dalam shalat, Agama yang dianut, macam-macam agama yang ada. Kemudian guru menentukan atau menyususn tempat duduka anak supaya anak bisa 
mendengarkan cerita dengan baik. Langkah senjutnya yatiu guru memulai cerita dengan menggali pengalaman-pengalaman anak dalam kaitan nya dengan shalat, agama yang dianut oleh peserta didik. Sebagai contoh guru menjelaskan bahwa kita semua beragama Islam, sehingga kita harus banyakbanyak bersyukur dengan apa yang telah diberikan Allah SWT kepada kita semua, Allah telah memberikan kita anggota tubuh yang lengkap sehingga kita harus senantiasa mengucapkan Alhamdulillah dan menjaga apa yang telah diberikan Allah kepada kita. kemudian kita sebagai umat Islam Kita wajib shalat karena itu adalah perintah Allah SWT, dimana kita harus beribadah kepada Allah SWT. Selanjutnya kegiatan penutup dilakukan dengan mengajukan berberapa pertanyaan-pertanyaan yang berhubungan dengan penanaman nilai agama dan moral serta menggunakan boneka tangan sebagai medianya. Selanjutnya guru memberikan pujian kepada anak yang berhasil menjawab pertanyaan guru.

Ketika melakukan observasi terlihat beberapa anak yang masih melakukan aktivitas lain ketika guru melakukan cerita. Hal ini disebabkan oleh bebrapa factor salah satunya kurang menarik nya cara guru dalam bercerita. Padahal guru sudah menggunakan media yang menarik. Seharusnya guru mampu bercerita lebih menari sehingga mampu meningkatkan daya piker dan emosi anak dalam menanamkan nilai agam dan moral pada anak.

Dalam peneltian ini, peneliti juga melakukan proses wawancara dengan seorang pendidika. Berdasarkan hasil wawancara yang peneliti lakukan, pendidik mengatakan bahwa dalam penanaman nilai-nilai moral dan agama yang dilakukan melalui metode bercerita ini, lembaga pendidikan ini memiliki program untuk melihat kemampuan seorang guru dalam melakukan metode bercerita dengan menggunakan boneka tangan. Diamana pada kegiatan tersebut, guru dilihat oleh anak-anak dan dilakukan dengan bersama-sama peserta didik yang lainnya setiap hari pada awal inti dan akhir kegiatan dengan guru memberikan contoh dan anak menirukan.

Berdasarkan hasil wawancara dan obervasi dapat peneliti simpulkan bahwa dalam penanaman moral dan agama terdapat metode bercerita yang dilakukan oleh guru berupa salat, jumlah rakaat dalam salat, bacaan-bacaan yang ada di dalam rakaat salat, do'a do'a pendek, doa untuk kedua orang tua. Selain itu juga itemukan adanya pengenalan anggota tubuh, anggota keluarga beserta fungsinya, dan tugasnya dengan menggunakan boneka tangan dimana agar anak dapat tertarik ketika guru bercerita, dalam kegiatan ini anak mampu mencapai ranah perkembangan nilai-nilai moral dan agama dalam ranah melaksanakan kegiatan ibadah sesuai dengan keyakinan yang dianut. 


\section{Metode Karyawisata}

Berdasarkan hasil observasi yang dilakukan oleh peneliiti, ditemukan adanya metode karyawisata dalam penanaman nilai-nilai moral dan agama pada peserta didik dengan penjelasan sebagai berikut:

a. Perencanaan karyawisata. Pada tahap ini yang dilakukan oleh guru yaitu mengajak peserta didik berkunjung ke kebun jeruk. Pada kegiatan ini anak terlihat sangat antusias, dimana dalam kegiatan ini anak mempunyai kesempatan untuk melihat buah jeruk secra langsung baik bentuk, warna dan rasanya. Sebelum peserta didik berangkat ke kebun jeruk, guru juga tidak lupa mempersiapkan alat dan bahan yang diperlukan untuk dibawa ke kebun jeruk, misalnya makanan dan minuman yang biasanya peserta didik bawa, guru mempersiapkan kantong plastic, obat-obatan. Alat tranportasi yang digunakan untuk menuju lokasi menggonakan angkutan kota (angkot). Masing-masing angkot diisi oleh peserta didik, guru kelas dan supir. Untuk memudahkan guru dalam mengawasi anak-anak sebelum berangkat guru mengabsen peserta didik berdasarkan nomer absen nya. Kemudian guru membacakan tata tertib, supaya peserta didik lebih tertib dalam mengikuti kegiatan karya wisata. Bekal yang dibawa peserta didik dibuka ketika sudah sampai di kebun jeruk, serta anak-anak diajarkan untuk sopan santun ketika berada disuatu tempat atau kebun jeruk dan sopan santun terhadap orang yang lebih tua.

b. Pelaksanaan karyawisata. Guru membagikan peserta didik menjadi kelompok-kelompok kecil, sebelum berangkat guru meminta peserta didik untuk berdoa surat al- fatihah, doa keluar rumah, dan ketika naik kendaranan, setelah itu peserta didik masuk ke dalam kendaraan mobil angkot yang dipandu oleh bu guru dan ketika sudah sampai di kebun jeruk peserta didik dibimbing oleh guru atau orang tua murid yang bersedia berpartispasi dalam kegiatan karyawisata ini. Untuk menjamin tertib ketika berada di kebun jeruk guru memberikan tata tertib yang harus ditaati para peserta didik. Misalnya tidak membuang sampah sembarangan, tidak memetic buah yang masih kecil karena jika buah buah yang masih kecil dipetik buah tersebut belum matang sehingga peserta didik jika memetik pilih lah buah yang besar, dimana ketika peserta didik memetik buah yang masih kecil lalu dibuka kulit nya dan anak akan meraskan apa rasa dari jeruk tersebut. Peserta didik sudah disiapakan plastik oleh bu guru untuk membuang sampah dan memasukkan hasil memetik yang di dapat oleh peserta didik, dengan kegiatan karyawisata ini mengajarkan anak kesebaran, rasa bersyukur kepada Allah SWT, dalam penanamana nilai-nilai moral dan agama guru memberikan metode karyawisata dengan berkunjung ke kebun 
jeruk, dan disana peserta didik menemukan pengalaman baru yang dapat memperluas pengalaman ataupun wawasan yang tidak pernah diketahui peserta didik sebelumnya ketika belajar di dalam kelas.

c. Tindak lanjut karyawisata.Setelah selesai melakukan kegiatan karya wisata, guru mengajukan beberapa pertanyaan yang berkaitan tentang penanaman nilai-nilai moral dan agama sebelum menutup kegiatan. Kemudian guru juga menanyakan perasaan siswa selama mengikuti kegiatan tersebut.

Berdasarkan hasil observasi tersebut dalam penanaman nilai-nilai moral dan agama di TK Goemerlang guru melakukan metode karyawisata dengan berkunjung ke kebun jeruk dengan mengajak peserta didik kesana dapat menjadikan peserta didik untuk selalu bersyukur kepada Allah SWT, merasa hati nya tenang dan selalu ingat dengan Allah SWT, sopan santun dan saling tolong menolong, Jadi kesimpulan yang didapat bahwa penanaman nilai-nilai moral dan agama dalam metode karyawisata dalam indikator menunjukkan perbutanperbuatan baik dengan mengajak peserta didik ke tempat objek-objek yang baru yang belum diketahui sebelumnya.

Hasil observasi tersebut diperkuat dengan hasil wawancara yang dilakukan oleh peneliti kepada salah seorang pendidik. Berdasarkan hasil wawan cara tersebut, pendidik menjelaskan bahwa melalui metode karya wisata tersebut, anak menjadi lebih mampu memahami bahwa Allah SWT maha pengasih lagi maha penyayang, hal ini karena anak bisa melihat langsung buah jeruk dan mengetahui bahwa buah tersebut ciptaan Allah, berdasarkan penjelasan pguru. mereka juga dapat merasakan hasil memetik buah yang telah didapat nya, dimana disana buah jeruk nya banyak dan kebun nya yang luas, sehingga ketika anak berada disana merasa bahagia.

Berdasarkan hasil wawancara, observasi dan dokumen analisis diatas maka dapat disimpulkan bahwa guru berharap anak-anak mampu bersyukur dengan semua yang telah didapatkanya, karena dengan bersyukur maka anak merasa hatinya tenang dan selalu ingat dengan Allah SWT. Hal tersebut juga berlaku pada guru-guru di TK Goemerlang Bandar Lampung sehingga pendidik bukan saja mejelaskan saja tetapi juga anak diberikan adanya praktik secara langsung dimana yang ada dalam metode karyawisata ini, anak-anak dapat langsung melihat ke kebun jeruk dimana dapat mengembangkan nilai-nilai moral dan agama para peserta didik.

\section{Metode Demonstrasi}

Berdasarkan hasil observasi yang dilakukan peneliti, metode selanjutnya yang digunakan oleh gur dalam penanaman nilai moral dan agama adalah metode demonstrasi, dengan penjelasan sebagai berikut : 
a. Langkah Pembukaan Demonstrasi. guru memberikan penanaman nilainilai moral dan agama pada anak dengan menggunakan metode demonstrasi melalui suatu kegiatan pembelajaran praktek shalat subuh.sbelum memulai kegiatan guru mengatur posisi peserta didik untuk kegiatan praktek shalat, selanjutnya guru memberikan penjelasan kepada peserta didik tentang kegiatan tersebut beserta tujuanya. Sehingga sisiwa mengetahui secara detai gerakan dan bacaan sholat subuh. Sebelum memulai kegiatan praktek shalat subuh anak-anak berbaris terlebih dahulu untuk mengambil air wudhu dan disini guru mengajarakan bagaimana cara mengambil air wudhu sesuai dengan urutan nya, guru pula mempersiapkan alat untuk praktek shalat.

a. Langkah Pelaksanaan Demonstrasi. Sebelum kegiatan pelaksanaan dimulai guru menanyakan kepada peserta didik tentang shalat subuh ada berapa rakaat kah, waktu shalat subuh di pagi hari atau disiang hari, guru memulai kegiatan praktek shalat ini dengan mengajak anak untuk mangambil air wudhu kemudian guru mempersiapkan alat dan bahan untuk shalat subuh untuk peserta didik yaitu mukena untuk anak yang perempuan dan topi untuk anak yang laki-laki dan sajadah, setelah peserta didik memakai mukena, topi guru membimbing peserta didik membuat barisan untuk kegiatan shalat subuh setelah itu guru meminta salah satu peserta didik untuk menjadi imam ketika shalat subuh yang dibimbing oleh bu guru ketika membaca bacaan ketika shalat subuh dan peserta didik mengikuti nya, setelah selesai salam iu tandanya peserta sudah selesai mengerjakan shalat subuh, kemudian guru meminta anak untuk berdoa secara bersama-sama, surat al-fatihah, istiqfar, doa untuk kedua orang tua. Setelah praktek shalat subuh selesai peserta didik melepaskan mukena dan topi yang telah dipakai, dan peserta didik kembali ke dalam kelas yang dibimbing oleh bu guru.

b. Langkah Mengakhiri Demonstrasi. Setelah kegitan praktek shalat subuh selesai guru menanyakan kepada peserta didik tadi kita sudah melaksanakan shalat apa anak-anak, kemudian peserta didik menjawab shalat subuh bu guru, berapa jumlah rakaat yang dikerjakan tadi peserta didik menjawab dua bu guru, kemudian guru memberi penjelasan kepada perseta didik bahwa shalat subuh hukum nya wajib bagi kita yang beragama Islam, jika tidak dikerjakan kita berdosa. Dengan adanya kegiatan shalat subuh ini peserta didik akan memberitahu kepada orang tua nya dirumah dan peserta didik akan mencoba mengerjakan salat subuh dengan orang tua nya, karena ketika di sekolah anak-anak sudah mencoba mengerjakan secara langsung.

Berdasarkan hasil observasi tersebut dalam penanaman nilai-nilai moral dan agama di TK Goemerlang, guru melakukan metode demonstrasi dengan melakukan praktek shalat subuh secara bersama-sama dengan mengajak peserta didik praktek 
shalat subuh untuk selalu bersyukur kepada Allah SWT, merasa hati nya tenang dan selalu ingat dengan Allah SWT, sopan santun terhadap orang yang lebih tua. Jadi kesimpulan yang didapat bahwa penanaman nilai-nilai moral dan agama dalam metode demonstrasi dalam indikator mempertunjukkan kepada peserta didik tentang suatu proses cara mengerjakan shalat sampai pada penampilan tingkah laku yang dicontohkan agar dapat diketahui dan dipahami oleh peserta didik secara nyata.

Selain melakukan observasi peneliti juga melakukan wawancara yang dilakukan dengan salah seorang pendidik. Dimana berdasarkan hasil wawancara tersebut guru menyatakan bahwa adanya praktek shalat subuh yang direncanakan setiap hari di ruang shalat secara bersama-sama dengan dipimpin oleh guru. Dengan adanya praktek shalat subuh ini diharapkan sebagai tempat bagi anak-anak untuk berlatih melakukan shalat dengan gerakan dan bacaan yang sesuai.

Berdasarkan hasil wawancara dan observasi yang didapatkan dari data data yang didapat diatas maka dapat disimpulkan bahwa adanya demonstrasi berupa shalat subuh yang dilakukan seorang pendidik dengan memberikan pengarahan kepada peserta didik untuk melaksakan shalat secara bersama-sama diruang sholat dengan catatan pendidik sedang tidak halangan atau ada kegiatan yang lain.

\section{Metode Pemberian Tugas}

Berdasarkan Hasil Observasi yang dilakukan oleh peniliti, bahwa ditemukannya metode pemberian tugas yang guru berikan untuk penanaman nilainilai moral dan agama pada peserta didik yakni:

a. Kegiatan Pra pengembangan. Sebelum memulai kegiatan guru memberitahu kepada peserta didik tema yang akan dibelajarkan hari ini, kegiatan yang dilakukan yaitu menempel bendera. Guru menjelaskan kegiatan yang akan dilakukan untuk memperingati hari kemerdekaan Indonesia bertepatan dengan dengan tanggal 17, sebelum kegiatan dimulai guru menanyakan kesiapan belajar anak, apakah sudah ada yang mengenal warna bendera negara Indonesia, ternyata sudah ada anak yang mengetahui bahwa bendera negara Indonesia adalah merah putih, merah melambangkan keberanian dan putih melambangkan kesucian. Setelah guru memberikan penjelasan kepada guru meminta anak duduk di tempat nya masing-masing, dan membagikan alat dan bahan yang akan digunakan untuk kegiatan menempel.

b. Kegiatan pengembangan. Setelah guru melakukan kegiatan pra pengembangan, selanjutnya guru memberikan kegiatan pengembangan dengan metode pemberian tugas, guru memberikan penjelas kepada anak bahwa kita akan melakukan kegiatan menempel bendera dan guru akan 
membagikan alat dan bahan yang digunakan, seperti lem, kertas warna merah dan putih, batang untuk menempel bendera, guru membagikan alat dan bahan kepada anak. Kegiatan menempel ini bertjuan agar anak mampu bersyukur atas nikmat yang telah Allah SWT berikan kepada warga Negara Indonesia, ketika anak-anak menempel bendera merah putih peserta didik dapat melatih kesabaran dan memiliki sikap saling tolong menolong kepada teman ketika kegiatan menempel bendera.

c. Kegiatan penutup. Setelah kegiatan pengembangan, guru mengulang kembali kegiatan pemberian tugas yang dilakukan hari ini, anak-anak menjawab menempel bendera bu, anak sudah mengetahui warna bendera dan artinya, berasal dari negara mana bendera tersebut, dengan adanya pembelajaran menempel ini melalui metode pemberian tugas peserta didik mampu merasakan kemerdekaan, dan peserta didik mampu bersyukur bisa mengikuti kegiatan hari kemerdekaan sehingga penanaman nilai-nilai moral dan agama anak dapat dikembangkan.

Berdasarkan hasil observasi tersebut, penanaman nilai-nilai moral dan agama di TK Goemerlang, guru melakukan metode pemberian tugas dengan melakukan kegiatan menempel bendera secara bersama-sama dengan mengajak peserta didik. Jadi disimpulkan bahwa penanaman nilai-nilai moral dan agama dalam metode pemberian tugas dengan indikator, guru telah memberikan alat dan bahan untuk tugas tertentu agar peserta didik melakukan kegiatan belajar.

Hal tersebut senada dengan hasil wawancara peneliti terhadap seorang guru, beliau mejelasakan bahwa pada saat anak-anak melakukan pembelajaran tersebut anak akan dilatih dalam penanaman nilai-nilai moral dan agama, dengan kegiatan menempel bendera saja, tetapi dengan adanya kegiatan-kegiatan yang lain yang dapat mengembangkan penanaman nilai-nilai moral dan agama anak usia dini.

Berdasarkan hasil wawancara dan obseravasi yang diperoleh, maka disimpulkan, bahwa penanaman nilai-nilai moral dan agama pada anak usia dini dapat dilakukan melalui permainan menempel bendera yang didukung dengan alat dan bahan yang sesuai untuk peserta didik.

\section{Metode Pembiasaan}

Hasil Observasi yang dilakukan di TK Goemerlang Sukarame Bandar Lampung, ditemukannya metode pembiasaan yang guru berikan untuk penanaman nilai-nilai moral dan agama pada anak antara lain: 
a. Metode pembiasaan. Ketika peserta didik datang ke sekolah yang diantarkan oleh orang tua baik ayah atau pun ibu, peserta didik tidak lupa bersalaman dengan guru yang sudah berada di depan gerbang yang menyambut peserta didik ketika datang ke sekolah, peserta didik bersalaman dengan semua guru yang ada di TK Goemerlang kemudian ketika berbaris peserta didik mampu membuat barisan dengan rapi dan ketika akan masuk kelas anak secara bergantian masuk kelas.

b. Sebelum guru memulai kegiatan pembelajaran, guru meminta salah satu anak memimpin doa di depan kelas, doa yang dibaca yaitu, doa sebelum belajar, surat al-fatihah, serta doa untuk orang tua, kemudian dilanjutkan dengan guru memberikan salam kepada anak, setelah itu guru memberikan instruksi untuk mengambil buku dan majalah, anak mengambil secara bergantian dan pada kegiatan ini mampu melatih kesabaran anak ketika berada di lingkungan sosial, sebagai contoh anak tidak saling dorong, setelah melakukan kegiatan pembelajaran anak bersiap untuk kegiatan makan bersama. Sebelum makan peserta didik berdoa, kemudin anak membuat barisan untuk mencuci tangan, ketika kegiatan mencuci tangan berlangsung anak mampu mengantri untuk menunggu gilirannya. Setelah makan peserta didik berdoa, kemudian anak siap untuk berdoa selesai belajar yang dipimpin oleh seorang anak, tidak lupa berdoa keluar rumah. Dan terakhir anak mengucapkan salam kepada guru begitu sebaliknya.

c. Dengan adanya kegiatan pembiasaan ini anak terbiasa melakukan kegiatankegiatan positif sehingga anak dapat menirunya, sehingga anak mampu melakukan kegiatan pembiasaan tanpa instruksi guru, sehingga peserta didik merasa senang.

Berdasarkan hasil observasi guru menggunakan metode pembiasaan dengan kegiatan yang baik, dimulai dari kedatangan anak ke sekolah sampai pulang. Dapat disimpulkan bahwa penanaman nilai-nilai moral dan agama dengan metode pembiasaan dengan indikator guru telah meningkatkan pembiasaan-pembiasaan dalam melaksanakan suatu kegiatan di sekolah.

Setiap hari setibanya anak di sekolah anak bersalaman dan mengucapkan salam dengan guru dan orang tua serta anak-anak lainnya. Kepala sekolah menjelaskan bahwa penanaman nilai-nilai moral dan agama tidak hanya bersalaman saja tetapi, mengantri juga merupakan sebuah pembiasan dalam penanaman nilainilai moral dan agama anak usia dini.

Berdasarkan hasil wawancara dan observasi, maka disimpulkan bahwa pelaksanaan penanaman nilai-nilai moral dan agama yang dilakukan guru dengan 
cara mencontohkan sikap yang baik yaitu mengucapkan salam dan terbiasa menunggu antrian, dengan demikian penanaman moral, lebih banyak dipergunakan melalui pembiasaan-pembiasaan tingkah laku dalam proses.

\section{Metode Bercakap-cakap}

Di TK Goemerlang Sukarame Bandar Lampung, ditemukannya metode bercakap-cakap yang dilakukan guru untuk penanaman nilai-nilai moral dan agama pada peserta didik yaitu:

a. Kegiatan pra-pengembangan. Sebelum kegiatan pra pengembangan guru mengajak anak untuk menyanyikan lagu rukun islam, agar anak lebih bersemangat dalam kegiatan selanjutnya dan memiliki keberanian untuk berbicara dan melatih kesungguhan mendengar ketika guru berbicara. Kegiatan bercakap-cakap pada hari ini yaitu tentang rukun islam.

b. Kegiatan pengembangan. Pada kegiatan pengembangan guru memulai dengan bercakap-cakap tentang rukun islam. Yaitu guru menyenyikan lagu rukum islam kemudian anak-anak mengikutinya. Selanjutnya guru menjelaskan tentang rukun islam, guru menjelaskan bahwa rukun islam itu ada 5 yaitu syahadat, shalat, puasa, zakat, dan haji. Selanjutnya peserta didik mengajukan berbagai pertanyaan kepada guru seperti mengapa kita harus berpuasa, kemudian guru menjawab karena kita beragama Islam sehingga kita wajib puasa, ketika bulan Ramadhan kita melakukan puasa, dan kemudian beberapa anak bercerita bahwa dia sudah perpuasa namun belum penuh, kemudian guru menjelaskan bahawa nanti anak-anak harus mulai belajar berpuasa.

c. Kegiatan penutup. Kegiatan pengembangan diakhiridengan kegiatan penutup, diaman guru menanyakan kepada peserta didik tentang perasaanya selama mengikuti kegiatan tersebut. Kemudian Peserta didik mengungkapkan bahwa ia ingin melakukan shalat, puasa dan lain sebagai nya ketika nanti sudah besar.

Hasil observasi tersebut menunjukan bahwa penanaman nilai-nilai moral dan agama yang dilakukan dengan metode bercakap-cakap seharusnya anak-anak dalam berkomunikasi mempunyai keterampilan mendengar dan keterampilan berbicara. tetapi yang peneliti lihat anak-anak belum mampu mengungkapkan perasaan nya ketika mendengar percakapan tentang rukun islam tersebut. Hal ini juga terkonfirmasi dari penjelasan guru bahwa ketika guru melalukan metode bercakap-cakap masih banyak peserta didik yang berbicara sendiri atau melakukan kegiatan lain. sehingga guru membuat metode bercakap-cakap dengan cara berbeda 
yaitu menanyakan tentang Rukun Islam dengan menggunakan gerakan dan lagu agar anak dapat tertatik ketika guru melakukan bercakap-cakap dengan peserta didik.

Berdasarkan hasil observasi dan wawancara diatas, bahwa metode bercakapcakap yang dilakukan oleh guru kepada siswa berkaitan dengan beberapa hal yaitu tentang bacaan syahadat, sholat, dll. Melalui metode bercakap-cakap ini, anak-anak belajar tentang moral dan agama.

Hasil penelitian tersebut menunjukan bahwa penanaman nilai moral dan agama di TK Goemerlang Bandar Lampung sudah diterapkan dengan baik menggunakan beberapa metode.hal ini sejalan dengan pendapat Plato bahwa perkembangan moral agama anak usia dini dapat dikembangkan pada awal kehidupan individu untuk dapat mengembangkan moral, anak dapat membedakan yang baik dan yang buruk, anak terbiasa dalam antrian, kebajukan, keadilan, kesederhanaan, dan keberanian ( Anki Lestaningrum, 2014: 201-202).

Metode pembelajaran yang digunakan dalam penanaman moral dan agama juga dilakukan dengan berbagai metode, yaitu :bercerita, karyawisata, demostrasi, pemberian tugas, pembiasaan, dan bercakap-cakap. Namun metode yang lebih sering digunakan dalam penanaman nilai moral dan agama ini adalah metode pembiasaan dimana metode ini dilakukan setiap hari. Karena peserta didik perlu adanya pembiasaan yang dicontohkan atau diberikan oleh seorang guru melalui perbuatan baik. Selanjutnya metode bercerita, bercakap, cakap, pemberian tugas demonstrasi dan karyawisata. Hal tersebut sejalan dengan prinsip pembelajaran AUD yang dikemukakan oleh yuliani, beliau menjelaskan bahwa anak belajar dari lingkungan dan dengan melalui sensori dan panca indranya (Nurani, 2013: 12). Dengan adanya contoh dari guru untuk sopan santun, melakukan sholat, saling tolong menolong. Penelitian sebelumnya mengatakan bahwa metode yang digunakan dalam penanaman nilai-nilai moral dan agama yaitu salah satunya dengan melalui metode bercerita. Namun pada penelitian sebelumnya mengatakan bahwa metode cerita cenderung lebih banyak digunakan karena anak usia dini biasanya senang jika mendengarkan cerita dari orang tua. Supaya peserta didik lebih tertarik dengan certia yang disampaikan oleh guru, tentunya cerita yang dibawakan harus tepat sesuai dengan usia anak. cerita yang dibawakan juga memuat nilai-nilai moral yang hendak disampaikan orang tua kepada anak.

\section{Simpulan}

Berdasarkan hasil penelitian yang dilakukan oleh peneliti selama satu bulan di kelas B2 TK Goemerlang Sukarame Bandar Lampung. Dapat disimpulakan bahwa dalam proses pembelajaran penanaman nilai-nilai moral dan agama anak usai dini 
telah dilakukan secara optimal. Adapun metode yang digunakan yaitu bercerita, karyawisata, demonstrasi, pemberian tugas, pembiasaan dan bercakap-cakap.[]

\section{Referensi}

Ananda, Rizki. (2017). “Implementasi Nilai-Nilai Moral dan Agama Pada Anak Usia Dini", Jurnal Obsesi: Jurnal Pendidikan Anak Usia Dini, Vol. 1, No. 1.

Inawati, Asti. (2017). "Strategi Pengembangan Moral dan Nilai Agama Untu Anak Usia Dini", Jurnal Pendidikan Anak, Vol. 3, No. 1.

Kemendiknas. (2014). Undang-Undang Republik Indonesia No. 20 Tahun 2003 tentang Sisdiknas. Bandung: Citra Umbara.

Khaironi, Mulianah. (2017). "Pendidikan Moral Pada Anak Usia Dini", Jurnal Golden Age, Vol. 1, No. 1.

Lestariningrum, Anki. (2014). “Pengaruh Penggunaan Media Vcd Terhadap NilaiNilai Agama Dan Moral Anak:, Jurnal Pendidikan Usia Dini, Vol. 8, No. 2.

Purba, Erna. (2013). Peningkatan Nilai-Nilai Agama Dan Moral Melalui Metode Bercerita Pada Anak Usia 4-6 Tahun. PG-PAUD FKIP: Universitas Tanjungpura Pontianak.

Santrock, John W. (2013). Perkembangan Anak. Jakarta: PT Gelora Aksara Pratama.

Sugiyono. (2014). Metode Penelitian Pendidikan Pendekatan Kuantitatif, Kualitatif, dan $R \mathcal{E D}$. Bandung: Alfabeta.

Sugiyono. (2016). Metode Penelitian Pendekatan Kualitatif Kuantitatif dan RED. Bandung: Alfabeta.

Sujiono, Yuliani Nurani. (2013). Konsep Dasar Pendidikan Anak Usia Dini. Jakarta: PT. Indeks.

Umayah. (2016). "Menanamkan Moral dan Nilai-Nilai Agama Pada Anak Usia Dini Melalui Cerita", Jurnal as-Sibyan, Vol. 1, No. 1. 